\title{
Dilemmas in the implementation of the World Health Organization Framework Convention on Tobacco Control
}

\author{
Dilemas na implementação da Convenção- \\ Quadro para o Controle do Tabaco da \\ Organização Mundial da Saúde
}

\author{
Dilemas en la implementación del Convenio \\ Marco para el Control del Tabaco de la \\ Organización Mundial de la Salud
}

Luciana Correia Borges 1
Henrique Zeferino de Menezes 2
Ielbo Marcus Lobo de Souza 2

doi: 10.1590/0102-311X00136919

\begin{abstract}
The article analyzes some dilemmas related to the implementation of the Framework Convention on Tobacco Control, underscoring the States parties' difficulties in adopting public policies with proven cost-benefit and aimed at reducing tobacco's supply and demand. Specifically, the article examines the recommendation to adopt policies for plain cigarette packaging, as provided in the guidelines for implementation of the Convention's Articles 11 and 13. Based on case analysis, we identified political and legal factors that hinder the Convention's implementation, including the regulatory chill produced by legal claims filed by the tobacco industry, which uses investor-State arbitration clauses from bilateral investment agreements. The article concludes that despite the costs imposed on States and the delays in the adoption of such policies, in the medium and long term the rulings handed down by the arbitration courts and the World Trade Organization's Dispute Settlement Body can consolidate the understanding of the legality and effectiveness of policies that adopt the model.
\end{abstract}

Public Policy; Tobacco; Tobacco-Derived Products Packing; International Cooperation

\author{
Correspondence \\ H. Z. Menezes \\ Universidade Federal da Paraíba. \\ Cidade Universitária s/n, João Pessoa, PB 58051-900, Brasil. \\ hzmenezes@ccsa.ufpb.br \\ 1 Secretaria de Estado da Educação e da Ciência e Tecnologia da \\ Paraíba, João Pessoa, Brasil. \\ 2 Universidade Federal da Paraíba, João Pessoa, Brasil.
}




\section{Introduction}

In recent years, noncommunicable diseases have gained increasing relevance on the Global Health agenda. Specifically, diseases associated with tobacco use have raised concerns due to the large number of victims and the associated social costs. Developing countries suffer heavily from the epidemic, with an increase in the number of smokers and their more precarious healthcare and social security systems, exacerbating the harmful effects of the product's consumption.

Consolidated scientific and clinical evidence of the correlation between tobacco use and a range of serious diseases has led to important responses for the reduction of tobacco's supply and demand through national and international public policies. The Framework Convention on Tobacco Control (FCTC) of the World Health Organization (WHO) is the most important global response to the tobacco epidemic, having been reconfirmed as an essential instrument through target 3.a of the Sustainable Development Goals (SDGs): "Strengthen implementation of the Framework Convention on Tobacco Control in all countries as appropriate”.

One of the Convention's fundamental thrusts is the implementation of policies to reduce tobacco products' commercial appeal, increasing the efficiency of the warnings on the harms of its consumption. Since the Convention's approval, other legal documents have emphasized the need for further progress with such policies. However, there has been some difficulty in the implementation of key elements of the Convention, especially those known internationally as "plain packaging laws". Numerous factors affect the decision-making and design of public policies related to this issue, placing various constraints on the States parties in enforcing such laws.

This article seeks to demonstrate how domestic and foreign factors have contributed to limiting the capacity of States' public intervention in this highly relevant area for public health. At the domestic level, the tobacco industry uses campaign strategies to delay or block changes in the rules to control and fight tobacco consumption. At the foreign level, arbitration claims by tobacco companies, based on agreements to protect foreign investment, have produced delays, alterations, or cancellations in the internalization of antismoking regulations in third countries - a phenomenon the literature has called the "chilling effect". Despite the initial costs produced by this type of international litigation, we contend in this article that in the medium and long term, the rulings by arbitration courts and the Dispute Settlement Body of the World Trade Organization (WTO) can consolidate the understanding of the legality and effectiveness of policies that adopt the Plain Packaging model.

\section{Global Health and the Framework Convention on Tobacco Control}

In recent decades, Global Health has been consolidated as a field of knowledge with a broad research agenda, but also with the design of collaborative strategies and actions focused on health problems and their national and international social determinants. Beyond the traditional characteristics of public health and international health, specifically actions in promotion, prevention, and recovery of human health beyond national borders, Global Health was founded on the ethical principles of social justice, equity, and solidarity, prioritizing equitable access to health in all regions of the world.

Notably, the consolidation of this concept of Global Health took place with multiple efforts by the international community to develop policies, raise funds, and implement mechanisms in response to the impacts of globalization on the social determinants of health, which in turn extrapolate the countries' individual control. In this sense, the notion of Global Health and its practices stem from a holistic, multisector, and multidisciplinary vision of regional and local contexts based on the understanding of the political, economic, social, and cultural forces that affect human health in various ways $1,2,3,4,5,6,7,8,9,10$.

Along this line, the establishment of new health patterns resulting from globalization, particularly the unequal distribution of diseases across the world population, led to an agenda for international governance focused on more equitable promotion and improvement of health for all peoples. In addition to emphasizing the strengthening of health systems and cohesion between different public policies, such as trade, foreign investment, and international development, the agenda incorporated as its main objective the control and regulation of international public health problems 11 . This category 
includes risk factors associated with chronic noncommunicable diseases, such as cardiac and respiratory diseases, diabetes, and cancer. According to projections by the WHO, by 2030 these diseases will account for $75 \%$ of all deaths in the world.

The harms from tobacco consumption have thus gained increasing growing evidence to the extent that studies have proven that smoking is a risk factor for all the above-mentioned diseases. Specifically, tobacco use and its externalities are related to 16 different types of cancer and are the leading risk factor for various chronic respiratory diseases. Smoking also causes hypertension and cardiac problems and is an independent risk factor for type 2 diabetes. Based on current trends, the WHO estimates that tobacco consumption will be responsible for 8 million deaths a year by 2030, with $80 \%$ of these deaths concentrated in developing countries.

Considering the globalization of the tobacco epidemic and the available information on the effects of tobacco use, a set of responses in the form of public policies have been proposed to emphasize the need to control the demand and achieve direct health results. Important international efforts have also been made to regulate the supply of tobacco products. The adoption of the FCTC, resulting from debates at the 52nd World Health Assembly in 2003, represented the most important multilateral global effort in this direction, since its provisions deal precisely with the control of tobacco products' supply and demand. The Convention rules on general principles, obligations, recommendations, and measures for the formulation of public policies on the production, marketing, promotion, advertising, sponsorship, and consumption of tobacco products. The FCTC also lays the groundwork for planning interventions and mobilizing political and financial resources to facilitate its complete implementation $12,13,14,15,16,17$.

The FCTC is the most widely accepted multilateral agreement in the history of the United Nations, with 181 countries having ratified the Convention and seven more countries having signed but not ratified it. It is the first normative international instrument in response to chronic noncommunicable diseases with a binding effect, that is, setting a legal obligation for all the Parties ratifying it. It is also the only world's only public health treaty focused on tobacco control policies 17 .

However, despite such extensive ratification, the binding overall nature, and the specificity and significance of its agenda, the main challenge for the WHO and the States parties comprising the FCTC Conference of the Parties (CP) is to guarantee enforcement of its provisions. This requires shedding light on three of the Convention's basic components, since most of the States parties of the FCTC experience difficulties in internalizing the guidelines according to the more comprehensive recommendations: the tool presented in the format of the acrostic MPOWER; the complementary instruments entitled Guidelines for Implementation; and the provision called Plain Packaging.

The MPOWER acrostic summarizes the strategy and action plan to implement the FCTC and achieve its object and purpose. The basis for this package of measures consists of the application of a set of public policies and interventions, with proven cost-benefit for tobacco control. The elements comprising this tool are found in Parts III and IV of the FCTC - specific sections focused on decreasing tobacco products' supply and demand. Each letter of the acrostic expresses and summarizes a current policy in the Convention's wording, offering the necessary instruments to serve its greater purpose of decreasing the supply and demand for tobacco 14,16,17,18,19:

$\mathbf{M}$ (monitor): monitor the use of policies to prevent tobacco use;

$\mathbf{P}$ (protect): protect the population from tobacco smoke;

$\mathbf{O}$ (offer): offer help for smoking cessation;

W (warn): warn of the dangers of tobacco;

E (enforce): enforce bans on advertising, promotion, and sponsorship; and

$\mathbf{R}$ (raise): raise taxes on tobacco.

Studies have reported some progress in decreasing the prevalence of smoking, since nearly twothirds of the States parties of the FCTC have already internalized at least one of the measures recommended by the MPOWER tool 13,20,21. However, the majority of the States parties, especially the developing countries, have not implemented the tool's measures at their most comprehensive level, opting to adopt the recommendations at the required minimum. This limitation becomes more latent when dealing with the measures to warn and enforce MPOWER, mostly provided in Articles 11 and 13 of the Convention. These articles deal with the adoption of measures to regulate tobacco products' packaging and labeling, as well as their advertising, promotion, and sponsorship. These measures aim 
to reduce tobacco products' attractiveness to consumers, increase the efficiency of the warnings of the harms caused by tobacco consumption, and ensure that consumers are not misled about tobacco's harmful effects 12,16,22.

More specifically, Article 11 recommends the use of pictorial warnings on the harms produced by tobacco consumption, covering at least $50 \%$ of the main outer packaging, while requiring a minimum of $30 \%$ of the cover. Here, the Parties have the autonomy to decide to implement the minimum requirement or internalize the recommendation more comprehensively. On packaging and labeling, beyond the warning's characteristic, there is no specific regulation in the Article on standardization in the use of the product's logotypes, markings, colors, and variations. The recommendations in this sense are generic, directed only to the ban on the use of deception to promote tobacco products and or any false and deceitful means to misrepresent the harms caused by tobacco 12,16,17.

Article 13 takes a slightly different approach, placing a total ban on tobacco advertising, promotion, and sponsorship, only allowing measures of a narrower scope due to restrictions imposed by the Constitution or constitutional principles. Note that the exception created by this provision is, in and of itself, a caveat to the general rule of treaty law, according to which a Party cannot invoke provisions of its domestic law to justify noncompliance with a treaty. In this case, the FCTC allows exceptions to the obligation it establishes in Article 13, based on provisions in the Party's domestic legislation, although requiring that such exceptions should obey constitutional hierarchy and not entirely prevent restrictive measures on advertising, promotion, and sponsorship of tobacco.

Along the same line as Article 11, Article 13's provisions are worded generically, with the objective of curbing the promotion of tobacco products and deceptions that minimize consumers' perception of tobacco's harms. Finally, likewise, Article 13 does not make specific recommendations on standardization of packages concerning the product's markings, logotypes, colors, and variations 16,17,22.

Despite the relevance of FCTC provisions on health warnings, more recent studies show that the enforcement of a policy on standardization of tobacco packaging and labeling is a key factor in the fight against smoking, attesting to the great potential for reducing false beliefs on the harms of different cigarette brands $23,24,25,26$. This led to the need to formulate additional instruments to assist full enforcement of the provisions in Articles 11 and 13, in addition to the consolidation of a specific provision to regulate standardization of tobacco products' packaging and labeling according to the above-mentioned studies' findings 27.

The Guidelines for the Implementation of FCTC Articles 11 and 13, a complementary instrument to the Convention adopted in 2008 28, resulted from a complex consultative and intergovernmental process established by the CP and are acknowledged as crucial to the Convention's implementation. The Guidelines provide more comprehensive measures on health warnings, recommending that the pictorial warnings cover more than $50 \%$ of the packages. They also provide specific guidance on all the content that should be contained on the packaging and labeling of tobacco products, presenting recommendations on each element comprising the products' design. The Guidelines also complement the recommendations of FCTC with less generic measures related to bans or restrictions on advertising, promotion, and sponsorship of tobacco products. All the Guidelines' content is based on studies proving each recommendation's cost-benefit ratio 27.

In keeping with the studies' findings and aimed at the implementation of more assertive policies and interventions, the Guidelines reached beyond the text of the Convention and established a new benchmark on packing and labeling, called Plain Packaging 27. Thus, based on incorporation of Guidelines for the FCTC, Plain Packaging emerged as a more advanced model for standardization of tobacco products' packaging. This provision is the third and last component to be described.

Specifically, Plain Packaging, present in the Guidelines for Implementation of Article 11, addresses regulatory measures to ban or restrict the use of logotypes, colors, brand images, or any other promotional device on tobacco products, also establishing a parameter for the display of brand names and variations in a single color and standard font. In the scope of the Guidelines for the implementation of Article 13 of FCTC, the provision on Standard Packaging indicates that standardization should be in black-and-white or in two other contrasting colors as determined by national authorities. It also provides that the packaging and labeling should not contain anything except the trade name, product name, and/or manufacturer's name, contact details, and amount of the product in the package. That is, this provision bans logotypes and other brand images. The font's style and size are preestablished, as 
are the shape, size, and materials allowed. Finally, there should be no advertising, promotion, or sponsorship inside or attached to the packaging or to individual cigarettes or other tobacco products 27.

Based on the terms by which the provision on Plain Packaging were addressed in the Guidelines, all the measures were formulated in order to achieve three main objectives. The first is the reduction of tobacco products' attractiveness. The second objective is the attempt to eliminate the effects of tobacco packaging as a form of advertising and promotion. Finally, an important objective for smoking control is to increase the noticeability and efficacy of health warnings 12,16,27.

The adoption of new national laws for standardization of tobacco product packaging and labeling according to Plain Packaging has helped achieve these objectives. The Australian government was the first to incorporate such standardization, approving the Tobacco Plain Packaging Law in 2011 (Law n. 148, 2011). Other developed countries such as the United States, France, and Norway soon implemented similar policies. Uruguay also made strides in packaging standardization but did not internalize all the measures indicated in the provision.

However, the degree of uptake by the developed countries is still incomplete. Even more seriously, no developing country internalized the full Plain Packaging standard. Thus, the majority of the States parties still comply only with the minimum required by the FCTC, failing to adhere fully to the provision or to the other recommendations in the Guidelines 12,29,30.

Although the FCTC is a binding international treaty for the parties, some of its provisions were clearly worded as recommendations, leaving some discretion as to their implementation. Accessory instruments like the Guidelines have an even greater legal limitation: they are not part of an additional protocol to the Convention and lack the binding force of an international treaty. Although a major share of its content can be properly characterized as recommendations adopted by the Conference of the Parties concerning a broader level of implementation of the above-mentioned articles, one should also acknowledge the possibility that the Guidelines also at least partly contained an authoritative interpretation of the FCTC provisions.

However, since both the FCTC and the Guidelines were endorsed by the States parties to the Convention, indicating their support for the policies promoted by the standards and Guidelines, how does one explain the low level of internalization of Plain Packaging by these same countries? The difficulties experienced by governments in implementing these measures result from a set of actions and strategies employed by the tobacco industry at the national and international levels.

Based on the above, the next section analyzes the dilemmas faced by the States parties in implementing standardization measures under the terms of Plain Packaging, aimed at shedding light on the problem to open the way for progress in the full and effective internalization of the Guidelines for Implementation of Articles 11 and 13.

\section{Dilemmas in the implementation of the Plain Packaging model}

The FCTC represents a considerable political and institutional step forward for Global Health, by formalizing an international normative framework for the control of tobacco consumption. However, when analyzing the adoption of the Plain Packaging policy, as defended by the WHO, the implementation has only occurred in some developed countries. Would this explain the wide gap between the number of ratifications and the level of the implementation of the Convention's more comprehensive provisions? Considering that States parties who ratify an international convention like the FCTC consent to being bound by its content and commit to promoting its object and purpose, there should be no reasons (other than technical and legislative incapacity) to not adhere to its provisions.

Several studies have focused on identifying and understanding the difficulties in the implementation of the FCTC. One of the main reasons for the low implementation of the FCTC lies in the economy. It goes without saying that the tobacco industry operates under the same logic as other industries, seeking to maximize profit, which necessarily requires increasing the consumption of tobacco products. At the government level, some countries are highly dependent on the tobacco industry for tax revenues, job creation, and attraction of direct investments. According to the Brazilian Association of Tobacco Growers (AFUBRA), Brazil is the world's second leading producer of tobacco leaves and processed tobacco, second only to China. The volume exported by these countries is also consider- 
able. As discussed by Souza 31, there is no short-term expectation towards a significant reduction in international demand for the product or a drop in its price. These countries face objective challenges for the implementation of international commitments that directly impact a productive sector which carries considerable weight in local economies.

In this context, the tobacco lobby emerges as a significant barrier to profound legislative changes that greatly impact the product's consumption, as in the case of Plain Packaging. The tobacco industry acts not only directly by lobbying decision-makers, but also by building support networks and pressure groups that seek to reduce or thwart changes in the rules for controlling and curtailing tobacco consumption. This strategy's efficacy is acknowledged by all, to the point that the Conference of the Parties includes, in the Declaration of Delhi, a paragraph that reiterates the need "to counter any efforts by industry and other non-State actors that work to further the interests of the tobacco industry to subvert and undermine government policies on tobacco control" 32.

Among the actions adopted by the tobacco industry, public campaigns have played an important role in counteracting Plain Packaging, as shown by the study by MacKenzie et al. 33 . These campaigns usually feature common elements such as the risks of trade in illegal products that produce more dramatic health problems and evasion of budget resources, the criticism for what they call the "nanny State" (which proposes to make decisions on individuals' life and liberty), and the lack of scientific evidence on the effect of plain packaging, which would actually take a biased view of the relationship between tobacco production and consumption ${ }^{33}$. One of the tobacco industry's central strategies in these campaigns is the use of deliberately misleading economic data and distorted social policy arguments to recruit public support 34 .

In addition to the advertising narrative, the tobacco industry uses other means to build support networks and defend its political and economic agenda. For example, it uses organizations not involved directly in production, in order, in the words of Gilmore et al. 34, to make the justifications more palatable leading to increased tobacco consumption. Finally, social responsibility practices and other means to coopt interests are used as a way to garner support, as highlighted in a report by the Brazilian National Cancer Institute (INCA) in 201735.

In addition to the domestic conditioning factors analyzed above, we argue that some factors external to government interests explain the States parties' difficulty in implementing the most relevant provisions of the FCTC. We specifically analyze the political and institutional reflections of the proliferation of international agreements to protect foreign investment and the companies' recourse to investor-State arbitration for trade dispute settlements. The risks and costs of litigation via arbitration presumably act as a threat and limiting factor, especially for lower income countries, in their attempts to implement public tobacco control policies. The specialized literature has referred to this as "regulatory chill". The following sections address the key elements in this discussion, the emblematic cases of investor-State arbitration involving the implementation of packaging standardization policies and the regulatory effects of this regulatory risk on preferential investment agreements.

\section{Foreign investment and regulatory chill}

Slow adherence to the Plain Packaging standard by the developed countries and the absolute lack of internalization of policies along these lines by the developing countries can also be explained by external regulatory and economic pressures. The crux of the issue lies in the fact that the implementation of health policies based on sovereign national authority allows loopholes for the tobacco industry to threaten States for alleged violation of trademark rights and expectation of profits from its investments. Pressure by the tobacco industry against FCTC measures is exercised the international level especially through the normative framework of Bilateral Investment Agreements (BIAs) and opening of panels in the WTO Dispute Settlement Body.

In the sphere of the WTO, the tobacco industry has benefited from actions by the countries in which it operates, by mobilizing the dispute settlement system against those States that are attempting to adopt more comprehensive tobacco control measures. A case study of implementation of the FCTC shows that the plaintiff countries based their claims on an alleged infringement of standards from the General Agreement on Tariffs and Trade (GATT), the Agreement on Trade-Related Aspects 
of Intellectual Property Rights (TRIPS), and the Technical Barriers to Trade Agreement. For example, when Australia adopted in full the Guidelines on Plain Packaging, Honduras, Dominican Republic, Indonesia, Cuba, and Ukraine filed legal challenges against the country (see cases DS434, DS435, DS441, DS458, and DS467 in https://www.wto.org/english/tratop_e/dispu_e/dispu_status_e.htm). Interestingly, these cases attracted considerable attention: 36 WTO members participate in the proceedings as third parties. With the exception of a proceeding filed by Ukraine - which reached the stage of installing a panel, later suspended at Ukraine's own request - in all the other cases the procedure is in the appeals phase in the Appellate Body.

Concerning BIAs, in addition to creating new understandings and forms of protection for foreign investment and intellectual property, including trademark rights, these agreements have gray areas on the protection of private property, investor safeguards, and State prerogatives. This link features two substantive key standards with a direct impact on trademark rights and consequently the implementation of tobacco control policies: the institute of expropriation and the principle of fair and equitable treatment $36,37,38$.

Direct and indirect expropriation is the first key standard of the standard BIA model. Direct expropriation occurs when a "government orders transfer of private property to the state", while indirect expropriation is defined as a government measure which, "while not expropriatory on its face, results in a 'taking' of the foreign investor's assets" 35 (p. 448). Based on this understanding, indirect expropriation can occur when investors' profit expectations are affected in equivalent fashion to that of an expropriation. The definition is thus vague, allowing interpretations that can impact various measures adopted by the State receiving the investment. In this sense, tobacco companies have claimed that policies following the Plain Packaging standard result in indirect expropriation of their trademark rights, jeopardizing their profit expectations 37,38 .

Fair and equitable treatment, according to the key standard of the standard BIA model, is an essential part of international common law. There is no consensus on its meaning, but there are two general lines of interpretation. First, governments "refrain from interfering with an investor's legitimate expectations". Second, governments must "avoid a denial of justice by acting in accordance with general principles of due process" 37 (p. 438). The wide scope assigned to this principle would leave room for interpretations that jeopardize the public interests of the State receiving the investment. Along this line, again, the tobacco industry contends that measures consistent with the more comprehensive recommendations of the FCTC violate this principle by interfering in the investor's profit expectations 36,37,38.

The BIAs also add new procedural standards for dispute settlements - the Investor-State Dispute Settlement (ISDS) system. This model formalizes investor-State arbitration as the ultimate mechanism for settling litigation, having exhausted negotiations and the internal legal appeals. InvestorState arbitration decidedly provides the opportunity for a foreign investor to take legal action against a receiving State, aimed at compensation for possible losses in expected profit or violation of due process, according to the rules for protection of the investment established in the agreement between the Parties. Thus, investor-State arbitration, as a mechanism of observance, allows the real imposition of costs or threat thereof 39 for the State purportedly violating the prerogatives provided in the agreement, sometimes, to the detriment of the social nature assigned to the government measures then considered as infringements $40,41,42,43,44$.

Drawing on these substantive and procedural standards, the tobacco industry has taken legal action against States that implement tobacco control measures, claiming, based on the loopholes created by the substantive standards described above, that such measures violate trademark rights and affront fair and equitable treatment. Consequently, such litigation has produced a phenomenon described in the literature as "regulatory chill". This occurs when the States' legislative autonomy "to enact certain regulatory or public policy measures" is negatively affected, generating delays, modifications, or cancelations of the internalization of a standard "as a result of arbitration, or a fear thereof, under investor-State dispute settlement ('ISDS') provisions" 45 (p. 2).

The inhibitory effect thus has a direct impact on the States' decision-making autonomy and capacity to regulate on issues of public interest. It is true that several variables can affect the decisionmaking process as to a law's enforcement, but it is possible to that the investor-State mechanism has caused regulatory chill and curtailed the political room for States to internalize policies that follow the Plain Packaging recommendations 45,46,47,48,49. 
Two emblematic cases can be cited on this phenomenon: "Philip Morris Asia Limited (PMA) v. Australia" (UNCITRAL, PCA Case n. 2012-12) and "Philip Morris Brands Sàrl, Philip Morris Products and Abal Hermanos v. Oriental Republic of Uruguay" (ICSID case ARB/10/7). Both cases illustrate the way that investor-State arbitration can affect the government's sovereign authority to regulate health-related public interests.

As regards the Australian case, despite the fact that the State justifies the Plain Packaging Law under the government's sovereign authority to implement public health measures, PMA launched a dispute under the ISDS system in the sphere of the Australia-Hong Kong bilateral investment agreement, claiming that the new law would interfere in the company's trademark rights, constituting an indirect expropriation. The tobacco lobby argued that its products had been turned into "unbranded commodities and 'substantially diminishing' the value of its investment in Austrália” 48 (p. 308). The intent behind the litigation was to prevent the policy's implementation in Australia and mainly to threaten other countries that were considering similar measures 30,49 .

In the Uruguayan case, the country has maintained a firm path in the implementation of policies that regulate tobacco advertising and use. By means of various decrees, rulings, and legislative amendments, the country steadily expanded it antismoking policy, featuring two measures: Decree $n$. 287-009/2009 and Ruling $n$. 514/2008. The former required pictorial warnings on $80 \%$ of all tobacco product packaging, front and back, superseding the previous 50\% requirement ("Regulation 80/80") and adhering to recommendations along the lines of Plain Packaging. On the same path, Ruling no. 514 determined that each brand name should be displayed only once ("Single Display Requirement"), so as to ban variations that could be considered misleading to consumers in relation to the safety and health of tobacco products. Therefore, the use of terms such as "light" and "ultra-light", for example, and the use of color-coded names, including "Marlboro Green (Fresh Mint)", were banned.

In response to the above-mentioned measures, Philip Morris International (PMI) issued a request for arbitration to the International Center for Settlement of Investment Disputes (ICSID) against Uruguay, based on the Switzerland-Uruguay bilateral investment agreement. The company claimed that the "Single Display Rule" and "Regulation 80/80" violated trademark rights, significantly impacting the tobacco company's profit expectations, protected by the agreement, and constituted an indirect expropriation. Thus, to back the claim, the company cited the occurrence of "indirect trademark expropriation" and violation of the "Principle of Fair and Equitable Treatment", exactly as in the case against Australia.

PMA and PMI accused the measures adopted by Australia and Uruguay of assuming a form of indirect expropriation, since the policies limited the use of brand name variations, effectively banning numerous variations sold by the company and thus affecting the brand's value and reducing profit expectations. Reduction of their profit expectations purported violated the Principle of Fair and Equitable Treatment, since the alteration of the regulatory environment through implementation of public policies focused on guaranteeing public health had altered investors' legitimate expectations.

Meanwhile, Uruguay's argument in particular was that the contested measures had been adopted according to the country's international obligations, including the Guidelines for the Implementation of Articles 11 and 13 of the FCTC and the rules for the protection of foreign investment, measures which had the sole purpose of protecting public health. According to the country, the rules were applied in non-discriminatory fashion to tobacco companies, exercising the government's sovereign authority in good faith and with reasonability. In this specific sense, the defenses of Uruguay and Australia converged significantly 30,48,49,50.

Recourse to arbitration had a direct negative impact on the countries in question, translated as the time and costs dedicated to legitimizing the interventions' binding nature. Meanwhile, the impacts are not limited to those that effectively initiated or implemented tobacco control policies of this nature. The literature reveals the existence of inhibitory chill on other governments that planned to implement similar policies and had "to weigh the costs of potential arbitration when making regulatory decisions" 49 (p. 158), considering that the filing of arbitration proceedings against government decisions had slowed down "other countries (...) to implement similar regulations" or "may have kept some countries from implementing new regulations at all" 49 (p. 160).

Uruguay began experiencing difficulty in the implementation of antismoking policies due to the arbitration proceedings. According to Jennifer Tobin, after the claim was filed, the Uruguayan gov- 
ernment opened a special session to discuss the "international repercussions of Uruguay's anti-tobacco legislation" 49 (p. 160). Due to the chilling effect of the arbitration process, Uruguay was unable to move forward with its growing implementation of policies to adopt the Plain Packaging standard 49.

Other countries were also impacted by the regulatory chill resulting from the above-mentioned cases. New Zealand considered the approval of a similar policy to the Plain Packaging Law enforced by Australia, but issued an "express declaration that the legislation would be suspended until the outcome of the (...) arbitration" 45 (p. 18) discussed above. The government's announcement emphasized the "risk that tobacco companies will try and mount legal challenges against any legislation, as we have seen in Australia" 45 (p. 17). The threat of costly and lengthy international arbitration resulted in an initial social cost, since the New Zealand government decided to await the arbitration ruling of PMA against Australia before approving its own health policy with Plain Packaging standards.

In addition to this case, a study by Jennifer Tobin 49 compiled examples of similar policies to the Plain Packaging Law that were delayed, curtailed, or canceled in response to the ISDS threat. The analysis concentrated on the Latin American countries, based on the countries' legislative committees, reports by the Special Sessions Commissions to discuss the matter, etc. According to the study's findings, Mexico reduced its tobacco control recommendations, with Congress having voted down a more rigorous version of the health warning policy to avoid domestic and international arbitration. In this case, the country required the minimum standard recommended by the FCTC, passing a law that determined only $30 \%$ of the package front to display pictorial health warnings $47,49,51$. The case of Guatemala is also emblematic. The country attempted to pass warning measures for tobacco control in 2010 and 2016, but both attempts failed. The main argument was that "strict tobacco regulations would violate freedom of enterprise and intellectual property rights guaranteed by the Constitution" 49 (p. 161), leaving Guatemala open to domestic and international claims. The country's Commission on the Economy and Foreign Trade (2010) also declared that "extending the pictograms to $\square 0 \%$ of the package would be tantamount to expropriation of private property, and violate constitutional and international commitments" 49 (p. 161-2).

Finally, the author discusses the cases of Honduras and Chile. Honduras reacted to the ISDS threat as Guatemala had done. The government passed a law in 2010 requiring $80 \%$ of the packaging to be covered with pictorial warnings. However, in 2011, the government reduced the percentage set by law to 50\%, "citing the possibility that the larger percentage would be a violation of international commercial commitments" 49 (p. 162). The Chilean government had studied extending the regulation beyond the FCTC requirement, making it similar to Australia's policies in the Plain Packaging Law. However, the Chilean legislators "feared that plain packaging would be seen as both arbitrary discrimination and a violation of intellectual property laws, both of which could result in domestic and international arbitration" 49 (p. 162).

All these cases confirm the inference that investor-State arbitration causes regulatory chill and limits the countries' legislative autonomy. In this case, countries are more likely to delay, curtail their intention, or fail to implement tobacco control policies, especially those following the Plain Packaging model. This means that the political room to enforce the FCTC Guidelines has been curtailed, since governments have not been skillful in implementing provenly efficient public policies that meet the public interests, due to the risks and costs involved in potential arbitration.

Despite the consequences identified in this area, it is possible that the final rulings in the proceedings against Australia and Uruguay by tobacco companies and national governments may generate a reverse effect in the future, encouraging other countries to adhere to the Plain Packaging model. The proceedings filed against Australia in the WTO Dispute Settlement System have already produced reports in the panels that rule entirely in the defendant's favor (although subject to appeals in the Appellate Body). In case they are upheld by the Appellate Body, the legislative measures that introduced the Plain Packaging model will have their legality acknowledged, given three highly relevant international instruments that address different intellectual property and foreign trade issues.

Australia has also dealt successfully with arbitration, based on a procedural technicality. The proceedings filed against Australia were ruled out of order. As a result, the arbitration court could not exercise jurisdiction on the merit of the dispute, and the legal costs had to be paid by the plaintiff (PCA 2012). As for the arbitration involving Uruguay, the court ruled against all the claims by plaintiffs Philip Morris and Abal Hermanos and ordered them to pay all the parties' court costs. The court ruled on the basis of the issues raised concerning the institutes of indirect expropriation and fair and 
equitable treatment to confirm the adequacy of the legislative measures adopted by the Uruguayan government (ICSID).

In this case, the WHO and the FCTC Secretariat intervened in the case in favor of Uruguay's position. Assessing its legal impact, Koh states that "the Uruguay decision will stand as an unequivocal landmark rebuke of the tobacco industry's trade arguments" 52 (p. 447). The court handed down its ruling in a context of legal victories by the UK government 53 and the European Union (Court of Justice, 2016), when they were challenged legally by tobacco companies for having adopted Plain Packaging.

However, one cannot rule out the possible aggregate impact of the panel reports by the Dispute Settlement Body and the arbitration courts: in addition to backing the recommendations in the Plain Packaging model in light of the various international instruments, they helped clarify the scope of the legal institutes of indirect expropriation and fair and equitable treatment. Rulings such as these will certainly be studied by the governments of States wishing to adopt the Plain Packaging model and can serve as the legal grounds and arbitration precedent in potential litigation in the future.

\section{Final remarks}

The FCTC legal framework has a multidimensional normative structure, including both binding standards and recommendations. A minimum threshold of legal obligations was established alongside a margin of autonomy for States that wished to meet the Convention's broader objectives. This more flexible formula guaranteed widespread adherence to the Convention by the States.

States' adherence to the Plain Packaging model has proven to be gradual and cautious, given the domestic obstacles and resistance by the tobacco industry. The effects of regulatory chill on some States parties to the FCTC are a visible manifestation of tobacco companies' successful strategy to prevent, block, or delay the adoption of domestic tobacco control measures. This strategy relates most directly to the imposition of economic costs on countries that intend to implement such policies and has the potential to produce short-term effects, in addition to impacting low-income countries more heavily.

However, in the medium and long term, the strategy tends to produce the opposite effect. The institutions created to back the FCTC legal framework, the Conference of the Parties and the Secretariat, have continuously promoted the implementation of more comprehensive tobacco control measures by issuing the Guidelines and the understandings on the Convention's provisions. A ruling by the Conference reflects the majority or unanimous position of the FCTC and thus the inclination of most of the international community towards the progressive elimination of tobacco use. In this task, the rulings have received institutional, political, and scientific support from a network of other international agencies and nongovernmental organizations. Tobacco control policies also enjoy the backing of related and broader legal frameworks, such as human rights, since the adoption of these control measures is now essential for ensuring the right to health and the rights for the protection of women and children.

The tobacco industry's claims, as discussed, had effects on the decision-making capacity of various countries that had planned to implement policies such as Plain Packaging. Meanwhile, the legal and arbitrations rulings have consolidated an interpretation that corroborates public tobacco control policies. 


\section{Contributors}

The authors participated equally in the study's development and drafting of the article.

\section{Additional informations}

ORCID: Luciana Correia Borges (0000-0002-72381346); Henrique Zeferino de Menezes (0000-00021385-7957); Ielbo Marcus Lobo de Souza (00000002-0335-6497).

\section{Acknowledgments}

The authors wish to acknowledge the financial support of the Brazilian National Research Council CNPq (Call for Projects MCTI/CNPq n. 28/2018 Universal) and the British government (Chevening Scholarships and Fellowships).

\section{References}

1. Beaglehole R, Bonita R. What is global health? Glob Health Action 2010; 3:10.3402/gha. v3i0.5142.

2. Buse K, Drager N, Hein W, Dal B, Lee K. Global health governance: the emerging agenda. In: Buse K, Hein W, Drager N, editors. Making sense of global health governance: a policy perspective. Hampshire: Palgrave Macmillan; 2009. p. 5-14.

3. Fidler D. International law and public health: material on and analysis of global health jurisprudence. Ardsley: Transnational Publishers; 2000.

4. Fidler D. After the revolution: global health politics in a time of economic crisis and threatening future trends. Glob Health Gov 2009; 145:1-21.

5. Garrett L. The challenge of global health. Foreign Aff 2007; 86:14-38.

6. Katz R, Komblet S, Arnold G, Lief E, Fischer JE. Defining health diplomacy: changing demands in the era of globalization. Milbank Q 2011; 89:503-23.

7. Kickbusch I. Global health governance: some theoretical considerations on the new political space. In: Lee K, editor. Health impacts of globalization. Basingstoke: Palgrave Macmillan; 2003. p. 192-203.

8. Koplan JP, Bond TC, Merson MH, Reddy KS, Rodriguez MH, Sewankambo NK, et al. Towards a common definition of global health. Lancet 2009; 373:1993-5.

9. Mcinnes C, Lee K. Global health and international relations. Oxford: Polity Press; 2012.

10. Ruger J. Normative foundations of global health law. Georgetown Law J 2008; 96:42343.

11. Buse K, Hein W, Drager N, editors. Making sense of global health governance: a policy perspective. Hampshire: Palgrave Macmillan; 2009.

12. Pan American Health Organization. Report on tobacco control for the Region of the Americas. WHO Framework Convention on Tobacco Control: 10 years later. Washington DC: Pan American Health Organization; 2016.

13. Pan American Health Organization. Strategy and plan of action to strengthen tobacco control in the Region of the Americas. Washington DC: Pan American Health Organization; 2017.

14. World Health Organization. Research for international tobacco control. WHO report on the global tobacco epidemic, 2008: the MPOWER package. Geneva: World Health Organization; 2008.

15. World Health Organization. WHO Framework Convention on Tobacco Control: guidelines for implementation of article 5.3, articles 8 to 14. Geneva: World Health Organization; 2013.

16. World Health Organization. WHO report on the global tobacco epidemic, 2017: monitoring tobacco use and prevention policies. Geneva: World Health Organization; 2017. 
17. World Health Organization. Tobacco. http:// www.who.int/news-room/fact-sheets/detail/ tobacco (accessed on 10/Jul/2019).

18. World Health Organization. WHO Framework Convention on Tobacco Control. Geneva: World Health Organization; 2003.

19. Wipfli H, Samet J. One hundred years in the making: the global tobacco epidemic. Annu Rev Public Health 2016; 37:149-66.

20. Cox A, Lutz B, Webb D, Sahal-Estime M, Small $\mathrm{R}$, Trivedi V. Development planning and tobacco control: integrating the who framework convention on tobacco control into UN and national development planning instruments. New York: United Nations Development Programme; 2014.

21. GBD 2015 Risk Factors Collaborators. Global, regional, and national comparative risk assessment of 79 behavioral, environmental and occupational, and metabolic risks or clusters of risks, 1990-2015: a systematic analysis for the Global Burden of Disease Study. Lancet 2015; 388:1659-724.

22. Mitchell AD, Studdert DM. Plain packaging of tobacco products in Australia: a novel regulation faces legal challenge. JAMA 2012; 307:261-2.

23. Wakefield M, Germain D, Durkin S. How does increasingly plainer cigarette packaging influence adult smokers' perceptions about brand image? An experimental study. Tob Control 2008; 17:416-21.

24. Wakefield M, Germain D, Durkin S. Do larger pictorial health warnings diminish the need for plain packaging of cigarettes? Addiction 2012; 107:1159-67.

25. Hammond D, Fong GT, McNeill A, Borland R, Cummings KM. Effectiveness of cigarette warning labels in informing smokers about the risks of smoking: findings from the International Tobacco Control (ITC) Four Country Survey. Tob Control 2015; 15:19-25.

26. Hammond D, Fong GT, Borland R, Cummings KM, McNeill A, Driezen P. Text and graphic warnings on cigarette packages: findings from the international tobacco control four country study. Am J Prev Med 2007; 32:202-9.

27. World Health Organization. Global progress report on implementation of the WHO Framework Convention on Tobacco Control. Geneva: World Health Organization; 2016.

28. WHO Framework Convention on Tobacco Control. Report on tobacco dependence and cessation (in relation to Article 14 of the Convention (decision FCTC/COP2(14)). https:// apps.who.int/gb/fctc/PDF/cop3/FCTC_ COP3_10-en.pdf.

29. Turia T. Government moves forward with plain packaging of tobacco products. Beehive. https://www.beehive.govt.nz/release/govern ment-moves-forward-plain-packaging-tobac co-products (accessed on 26/Feb/2018).

30. Hawkins B, Holden C, Mackinder SA. A multilevel, multi-jurisdictional strategy: transnational tobacco companies' attempts to obstruct tobacco packaging restrictions. Glob Public Health 2019; 14:570-83.
31. Souza R. Convenção Quadro para Controle do Tabaco: reflexões sobre o futuro da fumicultura brasileira. In: Anais do 47o Encontro da SOBER. Porto Alegre: Sociedade Brasileira de Economia Administração e Sociologia Rural; 2009.

32. WHO Framework Convention on Tobacco Control. Delhi Declaration. https://www.who. int/fctc/cop/cop7/FCTC_COP7_29_EN.pdf.

33. MacKenzie R, Mathers A, Hawkins B, Eckhardt J, Smith J. The tobacco industry's challenges to standardised packaging: a comparative analysis of issue framing in public relations campaigns in four countries. Health Policy 2018; 122:1001-11.

34. Gilmore A, Fooks G, Drope J, Bialous AS, Jackson PR. Exposing and addressing tobacco industry conduct in low income and middleincome countries. Lancet 2015; 385:1029-43.

35. Instituto Nacional de Câncer José Alencar Gomes da Silva. Quanto custa receber doações da indústria do tabaco. O art. 5.3 da Convenção Quadro da Organização Mundial da Saúde para o controle ao tabaco - a proteção das políticas públicas de controle ao tabagismo. Nota técnica. Rio de Janeiro: Instituto Nacional de Câncer José Alencar Gomes da Silva; 2017.

36. Correa CM. Public health and intellectual property rights. Glob Soc Policy 2002; 2:26178.

37. Gibson C. Latent grounds in investor-state arbitration: do international investment agreements provide new means to enforce intellectual property rights? In: Sauvant KP, editor. Yearbook on international investment law \& policy 2009-2010. Oxford: Oxford University Press; 2010. p. 397-476.

38. Alford RP. The convergence of international trade and investment arbitration. Santa Clara Journal of International Law 2014; 12:35-63.

39. Thompson A. Coercive enforcement of international law. In: Dunoff JL, Pollack MA, editors. Interdisciplinary perspectives on international law and international relations: the state of the art. Cambridge: Cambridge University Press; 2013. p. 502-23.

40. Correa CM. Investment agreements: a new threat to the trips flexibilities? South Bulletin 2013; (72):23-5.

41. Schill S. Crafting the international economic order: the public function of investment treaty arbitration and its significance for the role of the arbitrator. Leiden Journal of International Law 2010; 23:401-30.

42. Schill S. Reforming investor-state dispute settlement (ISDS): conceptual framework and options for the way forward. http://e15initiative. org/publications/reforming-investor-statedispute-settlement-isds-conceptual-frame work-and-options-for-the-way-forward/ (accessed on 19/Jan/2018)

43. Vadi VS. Public health in international investment law and arbitration. Abingdon: Routledge; 2013. 
44. Foster C. A new stratosphere? Investment treaty arbitration as internationalized public law'. Int Comp Law Q 2015; 64:461-85.

45. Shekhar S. Regulatory chill: taking right to regulate for a spin. http://wtocentre.iift.ac.in/ working a per /'REGULATORY\% 20 C H ILL\%E $2 \% 80 \% 99 \% 20$ TAKING\% 20 RIGHT\%20TO\%20REGULATE\%20FOR\%20 A\%20SPIN\%20(September\%202016).pdf (accessed on $02 / \mathrm{Feb} / 2018$ ).

46. Tienhaara K. Regulatory chill and the threat of arbitration: a view from political science. In Brown C, Miles K, editors. Evolution in investment treaty law and arbitration. Cambridge: Cambridge University Press; 2011. p. 606-27.

47. Schram A, Friel S, Vanduzer JA, Ruckert A, Labonté R. Internalisation of international investment agreements in public policymaking: developing a conceptual framework of regulatory chill. Glob Policy 2018; 9:193-202.

48. Hepburn J, Nottage L. A procedural win for public health measures. Journal of World Investment \& Trade 2017; 18:307-19.

49. Tobin JL. The social cost of international investment agreements: the case of cigarette packaging. Ethics Int Aff 2018; 32:153-67.
50. Dreyfuss RC, Frankel S. Reconceptualizing ISDS: when is IP an investment and how much can states regulate it? New York: New York University School of Law; 2018. (Working Paper, 18-23).

51. Fach Gómez K. Latin America. In: Krajewski M, Hoffmann RT, editors. Research handbook on foreign direct investment. Cheltenham: Edward Elgar; 2018. p. 494-522.

52. Koh H. Global tobacco control as a health and human rights imperative. Harvard International Law Journal 2016; 57:433-53.

53. High Court of Justice, Queen's Bench Division, Administrative Court. Case n.: CO/2322/2015, $\mathrm{CO} / 2323 / 2015, \mathrm{CO} / 2352 / 2015, \mathrm{CO} / 2601 /$ 2015 \& CO/2706/2015. https://slidelegend. com/judgment-courts-and-tribunals-judiciary _5b584dfa097c47fd588b4567.html. 


\section{Resumo}

$O$ artigo analisa alguns dilemas relacionados à implementação da Convenção-Quadro para o Controle do Tabaco, destacando as dificuldades dos Estados participantes para adotar políticas públicas, com custo-benefício comprovado, que visam à redução da oferta e demanda do tabaco. Especificamente, o artigo examina a recomendação para a adoção de politicas de padronização das embalagens de cigarro, presente nas diretrizes para a implementação dos Artigos 11 e 13 da Convenção. Por meio da análise de casos, identificamos fatores políticos e jurídicos que dificultam a implementação da Convenção, incluindo a inibição regulatória produzida pela abertura de litígios por parte da indústria do tabaco, que utiliza-se das cláusulas de arbitragem investidor-Estado existentes em acordos bilaterais de investimentos. Conclui-se que, apesar dos custos impostos aos Estados e dos atrasos na adoção dessas políticas, no médio ou longo prazo, as decisões proferidas pelos tribunais arbitrais e pelo Órgão de Solução de Controvérsias da Organização Mundial do Comércio podem consolidar o entendimento acerca da legalidade e efetividade de politicas que adotam o referido modelo.

Política Pública; Tabaco; Embalagem de Produtos Derivados do Tabaco; Cooperação Internacional

\section{Resumen}

El artículo analiza algunos dilemas relacionados con la implementación del Convenio Marco para el Control del Tabaco, destacando las dificultades de los Estados participantes para adoptar politicas públicas, con coste-beneficio comprobado, que tienen como objetivo la reducción de la oferta y demanda del tabaco. Específicamente, el artículo examina la recomendación para la adopción de políticas de estandarización de los paquetes de cigarrillos, presente en las directrices para la implementación de los Artículos 11 y 13 del Convenio. Mediante el análisis de casos, identificamos factores políticos y jurídicos que dificultan la implementación del Convenio, incluyendo la inhibición regulatoria, producida por la apertura de litigios por parte de la industria del tabaco, que recurre a cláusulas de arbitraje inversor-Estado, existentes en acuerdos bilaterales de inversión. Se concluye que, a pesar de los costes impuestos a los Estados, y de los atrasos en la adopción de esas políticas, en el medio o largo plazo, las decisiones proferidas por los tribunales arbitrales y por el Órgano de Solución de Diferencias de la Organización Mundial del Comercio pueden consolidar el entendimiento acerca de la legalidad y efectividad de políticas que adoptan el referido modelo.

Política Pública; Tabaco; Envasado de Productos Derivados del Tabaco; Cooperación Internacional
Submitted on $26 / \mathrm{Jul} / 2019$

Final version resubmitted on 23/Nov/2019 Approved on 02/Dec/2019 